NBER WORKING PAPER SERIES

\title{
VALUING AND PRICING RETAIL LEASES WITH RENEWAL AND OVERAGE OPTIONS
}

\author{
Patric H. Hendershott \\ Charles W.R. Ward \\ Working Paper 9214 \\ http://www.nber.org/papers/w9214

\section{NATIONAL BUREAU OF ECONOMIC RESEARCH 1050 Massachusetts Avenue Cambridge, MA 02138} \\ September 2002
}

Earlier versions of this paper were presented at the 2001 AREUEA Meetings in New Orleans, the University of Melbourne, the 2001 Cambridge-Maastricht Symposium and the University of Wisconsin. We thank participants at these presentations, especially Andrey Pavlov, for their useful comments. The views expressed herein are those of the authors and not necessarily those of the National Bureau of Economic Research.

(C) 2002 by Patric H. Hendershott and Charles W.R. Ward. All rights reserved. Short sections of text, not to exceed two paragraphs, may be quoted without explicit permission provided that full credit, including (C) notice, is given to the source. 
Valuing and Pricing Retail Leases with Renewal and Overage Options

Patric H. Hendershott and Charles W.R. Ward

NBER Working Paper No. 9214

September 2002

JEL No. G0, G3

ABSTRACT

We consider retail leases with landlord overages options, with tenant renewal options, with both and with neither. We illustrate how the ratio of initial expected sales to the sales threshold can be manipulated to equate the value of the landlord overage options to that of the tenant renewal option at the same initial rent. As a result, not only are the values of the dual option - overage plus renewal lease - and no option leases are equal, but the cumulative distributions of potential IRRs on the two leases are nearly identical, suggesting that these leases are equally attractive to risk-adverse investors and thus that the same risky discount rate can be used in valuing the leases. The analysis is carried out in a risk-neutral framework, and sensitivity of the results to interest rate uncertainty, real sales volatility and growth, and the required risk premium on retail real estate is shown. The appropriate risky discount rate for the overage lease is calculated to be 75 to 160 basis points greater than that for the renewal lease.

Patric H. Hendershott

Aberdeen Business School

University of Aberdeen

Aberdeen AB24 3UF

and NBER

phh3939@uslink.net
Charles W.R. Ward

Dept of Real Estate and Planning

University of Reading

Reading RG6 6AW

c.ward@rdg.ac.uk 


\section{Introduction}

U.S. shopping center leases are possibly the most idiosyncratic and complicated property leases in the world. Most of these leases contain both an overage rent clause and at least one renewal option. ${ }^{1}$ Both the landlord and the tenant can have options to cancel the lease, and tenants can have expansion, contraction, sublease and other options. These options are included in the contract because they are "positive sum games" - the value to the party receiving the option is greater than the cost to the party "giving" the option so that the latter can be adequately compensated via an adjustment in the rent paid. The source of the positive sum or net gain can be a reduction in payments to third parties, stronger incentives for tenants or the landlord to exert greater effort, or better risk sharing. ${ }^{2}$ In a competitive market, the net gain is passed through to consumers as lower prices.

While a vast literature exists on valuing options in property financial contracts (especially mortgages), including an empirical literature on the ruthlessness with which borrowers exercise their options, the analysis of leasing contracts is relatively limited. ${ }^{3}$ In this paper we consider the two most common retail lease options, those on overage rents and renewals. The overage clause is effectively a series of landlord options, giving him/her higher annual rents in years when tenant sales are particularly strong (the success of the business, measured in sales, determines the rent paid). The renewal, on the other hand, is a tenant option generally allowing the tenant to renew either at the original terms, at those grown at the current expected inflation rate or by cumulated inflation since the lease was originated, or at "market." Except for the latter, this allows the tenant that has done particularly well to limit the increase in rent on renewal.

Of course, an overage rent contract with a base rent equal to the rent on an otherwise identical lease contract without overages has greater value than the otherwise identical lease.

\footnotetext{
${ }^{1}$ Eppli et. al. (2000) report that over 90 percent of their sample of nearly 5000 leases have overage clauses. Stanton and Wallace (2000) report a 0.93 mean number of renewals in their sample of 357 leases.

${ }^{2}$ A growing literature exists on this topic. See Brueckner (1993), Colwell and Munneke (1998), Miceli and Sirmans (1995), Pashigan and Gould (1998b), and Wheaton (1999).
} 
Similarly, a lease contract with renewals and the same rent as that on an otherwise identical lease without renewals has less value than the otherwise identical lease. But lease contracts giving a specific type tenant control over the same space for the same time period cannot have different values in a competitive market (Grenadier, 1995, McConnell and Schalheim, 1983, and Ward, 1982). Thus leases with overage rent clauses have lower base rents than straight fixed-rent leases with the same other terms, and leases with renewals have a higher rent than otherwise identical leases without them. This paper "prices" these alternative leases - computes estimates of how the initial rent should vary across different contract structures giving the tenant control over the same space for the same time period. The variation depends on the economic environment (expected drifts and volatilities in rents and sales), as well as on how tenant rents are determined on renewal dates in the absence of exercise of a renewal option.

If landlords have call options on overages and give tenants a renewal put option, it should be possible to structure the contract to equate the values of the two options in a given economic environment. If this is done, a lease containing both options should have the same initial rent as a lease without the options. This would be especially convenient for valuers or appraisers, who do not appear to be skilled at valuing options. We show that this equality in option values can be achieved by adjusting the ratio of initial sales to the sales threshold - setting the overage options the appropriate distance out of the money. Moreover, the required ratio is relatively insensitive to the drift and volatility in real sales and the risk premium required on investment in shopping center leases.

We find that leases with overage and renewal options can be structured such that not only are the risk-neutral values of the two options equated at the same initial rent, but a lease containing both options generates a cumulative distribution of potential IRRs that largely mimics that of a nooption lease. In contrast, the cumulative distributions of IRRs for equal-valued renewal and

\footnotetext{
${ }^{3}$ For an elegant recent analysis of mortgage options, see Deng, Quigley and Van Order (2000); for an in depth analysis of lease options, see Grenadier (1995).
} 
overage leases differ sharply. The renewal contract tightens the distribution, truncating the upper end via the tenant exercising his/her option, while the overage rent contract has a wider distribution of potential IRRs because the overage component generates a long tail to the right. As a result, the renewal contract stochastically dominates the overage contract for risk-averse investors. ${ }^{4}$

Our analysis is initially carried out in a risk-neutral framework: the risk-free rate is used to discount the cash flows and the real sales drift employed in the analysis is the risk-neutral drift, the expected real drift less the required risk premium on the underlying asset (Hull, 2000, pp 248-249). Owing to uncertainly regarding both the expected real sales drift and the required risk premium, a series of calculations is presented. We then redo the simulations holding value constant and using the expected real drift in sales in order to obtain estimates of the risky discount rates for the four leases. We find that the overage discount rate exceeds the renewal discount rate by one to one and a half percentage points, which is consistent with the renewal contract stochastically dominating the overage contract. ${ }^{5}$ Moreover, if the same risky discount rate were mistakenly used to value renewal and overage leases that by construction have equal values, the computed overage lease value would exceed the computed renewal lease value by as much as 12 percent.

The remainder of our paper is divided into five sections. In Section II, we discuss the computation methodology employed and the key assumptions underlying our calculations. Section III describes the specific leases analyzed. In Section IV, rent premiums/discounts are reported for leases with renewal/overage options in low (two percent) and high (eight percent) inflation environments in a risk-neutral world. Also reported is the ratio of the sales threshold to initial sales that equates the value of the dual option lease to that of the no option lease. Estimates of the risky

4 Stochastic Dominance of the second degree implies that distribution of returns for asset A dominates asset B if $\int_{n}^{m} A(x) \cdot d x \leq \int_{n}^{m} B(x) \cdot d x$ where $\mathrm{A}(\mathrm{x})$ and $\mathrm{B}(\mathrm{x})$ are the cumulative distribution functions of $\mathrm{A}$ and $\mathrm{B}$ respectively for investors who prefer more to less and are risk averse defined as having utility functions with the properties, $\mathrm{U}^{\prime}(\mathrm{x})>0$ and $\mathrm{U}^{\prime \prime}(\mathrm{x})<0$ (Vickson, 1975).

5 This is, of course, a major advantage of risk-neutral discounting. One need only specify the underlying risk premium (about which we probably have the best intuition) as opposed to different risk premia for each contract (different options) available. 
discount rates for the four leases under different assumptions regarding the underlying real estate risk premium are reported in Section V. Section VI summarizes and concludes.

\section{Underlying Methodology and Assumptions}

We consider the leasing of space for twenty years with four different lease structures. The standard or base lease has a fixed rent for ten years at which point it adjusts up or down in line with the change in market rents on ten-year fixed rent leases. The second lease is similar except that the tenant has the right to renew at the end of the tenth year at the initial rent inflated by cumulative general inflation. The third lease is a 10 -year overage rent contract that rolls into another 10 -year overage contract in the tenth year. The tenant pays a base rent B plus overage rents equal to a fraction, f, of the excess of sales over a stated sales threshold, ST. The lease has a natural breakpoint $(\mathrm{ST}=\mathrm{B} / \mathrm{f})$ so the total rent paid in any year is

$$
R_{t}=\max \left[B, B\left(S_{t} / S T\right)\right]
$$

The final contract combines the second and third contracts, i.e., it is the overage rent contract but with the tenant having the right to renew at the end of the tenth year at the initial base rent inflated by cumulative rent inflation (a combination dual option, overage plus renewal, lease).

The values for initial one-year real rents and sales are arbitrarily set at $\$ 10$ and $\$ 100$ dollars and the price level at unity. ${ }^{6}$ In our basic calculations, we assume zero risk-neutral drift (drift less risk premium) for the real variables and either two or eight percent drift in nominal prices. The real risk-free rate of interest is set at four percent, giving a nominal risk-free discount rate, $r$, of either six or twelve percent. To obtain the initial 10-year fixed rent on the base contract, $\mathrm{R}_{0}$, we use the

\footnotetext{
${ }^{6}$ Data from existing leases in 1985 suggest that the ratio of rent to sales for nonanchor tenants is about 0.08 (see Table 1 below). Because nominal sales rise over time, the ratio of rent to initial sales on new leases would be higher.
} 
condition that the present value of the fixed rent for ten years must equal the present value of the expected 10-year stream of one-year rents, R1. The former is simply

$$
V_{10}=\left(R_{0} / r\right)\left[1-(1+r)^{-10}\right]
$$

With one-year rents expected to grow at rate $\mathrm{g}$ and rent payable annually in arrears, the latter is

$$
V_{1}=[R 1 /(r-g)]\left\{1-[(1+g) /(1+r)]^{10}\right\} .
$$

Equating (2) and (3), $\mathrm{R}_{0}$ is an explicit function of $\mathrm{R} 1, \mathrm{r}$, and $\mathrm{g}$ (Ward, 1982). We use this function to obtain $\mathrm{R}_{0}$ values for our simulations using different growth and interest rate assumptions and setting R1 equal to $\$ 10$.

Two geometric Brownian motion processes drive our estimates of lease contract value, those for the general price level and for real sales. To illustrate, the process for real sales is, in continuous time,

$$
d \ln S=\left(\mu-\sigma^{2} / 2\right) d t+\sigma d z
$$

where $\mu$ is the drift in real sales, $\sigma$ is its volatility and $\mathrm{dz}$ is a Wiener process. Because of the difficulty in obtaining a closed form solution for the overage rent contract and because we wish to obtain the distribution of present values, we use a Monte Carlo approach to solve for the value of different lease contracts. In effect this means that we replace the continuous sales process with the discrete process ${ }^{7}$

$$
\mathrm{S}(\mathrm{t}+\Delta \mathrm{t})=\mathrm{S}(\mathrm{t}) \exp \left[\left(\mu-\sigma^{2} / 2\right) \Delta \mathrm{t}+\sigma \varepsilon \sqrt{ } \Delta \mathrm{z}\right]
$$

\footnotetext{
${ }^{7}$ See Hull (2000) for further discussion of the Monte Carlo technique.
} 
where $\varepsilon$ is a random sample from a normal distribution $($ mean $=0$, standard deviation $=1)$.

Nominal sales are calculated by

$$
\text { Nominal Sales }_{\mathrm{t}}=\text { Nominal Sales }_{\mathrm{t}-1}\left(1+\% \Delta \text { RealSales }_{\mathrm{t}}\right) *\left(1+\% \Delta \text { PriceLevel }_{\mathrm{t}}\right)
$$

where $\% \Delta$ RealSales $_{t}=$ the percentage change in real sales from time $\mathrm{t}-1$ to $\mathrm{t}$ and $\% \Delta$ PriceLevel $_{\mathrm{t}}=$ the percentage change in prices from time $\mathrm{t}-1$ to $\mathrm{t}$.

Interest rates are assumed to be constant although more complicated models involving stochastic interest rates may easily be generated using the Cox, Ingersoll and Ross (1985a) or Hull and White (1993) models. Expected volatilities are two percent for the price level and 20 percent for real sales. The latter is high because the relevant variable is individual tenant sales in a specific shopping center. Owing to the uncertainty regarding this volatility, we also do simulations for volatilities of 10 and 30 percent. The risk-neutral real sales growth rate is assumed to be zero. Again owing to uncertainty regarding this parameter, we also run simulations with alternative rates. The base lease consists of a rent fixed for the first ten years. The rent is then fixed for another ten-year period. How we should specify the rent a specific tenant will pay during the second decade is not obvious. There are two general alternatives. First, rent could be set at "market" - at the initial rent inflated by the cumulative growth in the nominal fixed rent since origination. This assumes that retail rents of all tenants in a market grow at the same rate over time. Second, retail rents could be set at the initial rent inflated by cumulative nominal individual tenant sales growth since origination. This assumes that renewing tenants are charged according to their ability to pay as reflected in their sales revenue (e.g., tenants that have twice the sales per square foot pay twice the rent). In defense of this assumption, a tenant that is doing well can afford higher real rents and does not want to pay the costs of moving, including possibly much poorer sales, to a 
new location. And a tenant that is doing poorly cannot afford market rents, and landlords do not want to pay the costs of vacant space (zero rents for a period and lease up costs).

Data on median rent and median sales per square foot for department stores (anchors) and five classes of other tenants in 125 Superregional (over 850,000 square feet) and 99 Regional $(200,000$ to 850,000 square feet) malls are shown in Table 1 . Note that for both mall classifications rents of jewellery stores are roughly double those of clothing and accessories, shoes and gift/speciality shops, with food service lying approximately midway between these extremes. Most of this variation is explained by differences in sales. ${ }^{8}$ The last column is the ratio of rent to sales, and the variation in this ratio is quite small. These data do suggest that tenants are charged according to their ability to pay.

We shall assume that rents during the second decade equal the initial rent adjusted by the cumulative change in tenant sales since the lease was originated. ${ }^{9}$ To illustrate the importance of this assumption, we report simulations in the appendix where rents in the second decade are linked to the change in market rents rather than in individual tenant sales. (The difference in results follows from a much lower assumed volatility in market rents than in individual tenant sales.) In each simulation, rent during the second decade will differ from the level anticipated at the beginning of the first lease, but on average the fluctuations around the expected level are specified so that the expected present value of the second ten-year period rent will be unaffected by the fluctuations. In other words, the implied sales (market rent) growth at the start of the lease is an unbiased estimate of the average sales (market rent) growth during the initial ten-year period.

To reduce the Monte Carlo estimation time, we set the time period as one year. More accurate estimates might use a quarterly interval with quarterly cash flows but the extra time

\footnotetext{
${ }^{8}$ Eppli et. al. (2000) find a similar positive relationship between rent and sales.

${ }^{9}$ While tenants will generally be charged rent based on their ability to pay, extremes are likely to be truncated. If a tenant does extremely well relative to other tenants in a center, the threat to leave the center will be credible. Thus the tenant will be able to dampen the increase. On the other hand, if a tenant does sufficiently badly relative to other tenants, the tenant will be replaced and the new tenant will pay the local market rent for that class of tenant. Incorporating this realism would require a number of arbitrary assumptions and the inclusion of another Brownian motion process (for real rents) without altering the basic point being made.
} 
involved in iterating over 80 periods rather than 20 would add little to the demonstration. Monte Carlo simulation has long been used in option pricing, especially where path-dependent options are valued. For a comparatively recent application in real estate, see Hughes (1995).

We used 25,000 simulations to calibrate the value of each lease and then used an optimizing process $^{10}$ to estimate the premium or discount on the base rent that would equate the means of the present values of the different leases. That is, we impose the equilibrium condition that space rented for the same period must have the same value for any structure of leases (Grenadier, 1995, McConnell and Schalheim, 1983, and Ward, 1982).

\section{Specific Lease Contracts Analyzed}

We compute the present value of 20-year cash flow streams for four lease structures.

No Option Lease. The rent is assumed to be fixed for the first ten years at which point the initial rent is increased by the cumulative change in sales during that 10 -year period and held at that level for the next decade. The value of this rental stream is:

$$
V=\sum_{t=1}^{10} \frac{R o}{(1+r)^{t}}+\frac{1}{(1+r)^{10}} \sum_{t=1}^{10} \frac{R_{10}}{(1+r)^{t}}
$$

where $R o$ is obtained by equating equations (2) and (3) and solving, $R_{10}=R_{\mathrm{o}} \prod_{t=1}^{10}\left(1+s_{t}\right), s_{t}$ is the nominal sales growth in period $\mathrm{t}$, and $\mathrm{r}$ is the discount rate.

Renewal Lease. The rent for the second (renewal option) lease is also fixed for ten years but is then adjusted to be the lower of the sales-adjusted rent at that point and the original rent increased by the

\footnotetext{
${ }^{10}$ OptQuest running under Crystal Ball and Evolver running under @Risk were both employed.
} 
cumulated change in the price level over the intervening 10-year period. Thus the value of the rental stream is computed as

$$
V=\sum_{t=1}^{10} \frac{\operatorname{Ro}(1+\text { prem })}{(1+r)^{t}}+\frac{1}{(1+r)^{10}} \sum_{t=1}^{10} \frac{\min \left[R_{10}, R o \prod_{t=1}^{10}\left(1+p_{t}\right)\right]}{(1+r)^{t}}
$$

where $p_{t}$ is the inflation rate in period $t$. Note that if the renewal option is not exercised, the rental rate for the $11^{\text {th }}$ year is set at the non-renewal 10-year lease rate.

Because the renewal lease allows the tenant to pay a lower rent during the second ten years than is paid on the no-option lease, the equilibrium condition requires that the landlord earn a premium rent for the first ten years. We first estimate the present value of a renewal option lease assuming that a premium is not earned (we set prem in the equation equal to zero). We then calculate, by means of an optimizing procedure, the premium on the initial market rent that would have to be charged by the landlord on the renewal option lease so that the renewal lease would be worth the same present value as the no-option lease.

Overage Lease. The third lease offers the tenant a concession (or discount, dis) of a lower base rent in each ten-year period in exchange for the possibility of having to pay overages. In this case, having set the threshold sales/initial sales ratio, we can estimate the expected overages that would be payable for any given base rent. The sales threshold is reset at the start of the second decade to the original ratio to current sales so that overages will kick in during the second 10 -year term in the same way as observed in the first ten years. We apply the same discount to both the first and second ten-year periods. Given that we are assuming a natural breakpoint $(\mathrm{B}=\mathrm{fST})$. An x percent reduction in the base rent is also an $\mathrm{x}$ percent reduction in the threshold. The present value of the 20 -year cash flow stream is: 
$V=\sum_{t=1}^{10} \frac{\operatorname{Max}\left[\operatorname{Ro}(1-d i s), \operatorname{Ro}(1-d i s)\left(S_{t} / S T_{1}\right)\right]}{(1+r)^{t}}+\frac{1}{(1+r)^{10}} \sum_{t=1}^{10} \frac{\operatorname{Max}\left[R_{10}(1-d i s), R_{10}(1-d i s)\left(S_{t+10} / S T_{11}\right)\right]}{(1+r)^{t}}$

where $\mathrm{ST}_{11}=\mathrm{ST}_{1}\left(\mathrm{R}_{10} / \mathrm{Ro}\right)$.

Again we first estimate the average present value of the overage lease using, as the base rent, the market rent payable on the no-option lease (we set dis equal to zero), and then we compute the discount on the base rent that, together with the overages, will yield the same value as that of the no-option lease. Thus the base rent is expressed as a percentage discount on the initial market rent of the no-option lease.

Dual Option Lease. The fourth lease is a combination of the renewal and overage leases. In this case, the tenant may pay overages during the term of the lease. At the end of the tenth year, however, the tenant has the right to renew at the initial base rent increased by cumulated inflation over the 10-year period rather than at the initial base rent increased by cumulated sales over the 10year period. The value is then:

$\left.V=\sum_{t=1}^{10} \frac{\operatorname{Max}\left[\operatorname{Ro}(1+x), \operatorname{Ro}(1+x)\left(S_{t} / S T_{1}\right)\right]}{(1+r)^{t}}+\sum_{t=1}^{10} \frac{\left.\operatorname{Max}\left[R_{10}^{*}(1+x), R_{10}^{*}(1+x)\left(S_{t+10} / S T_{11}\right)\right]\right]}{(1+r)^{t}}\right\}$

where $\mathrm{R}_{10}^{*}=\min \left[R_{10}(1+x), R_{\mathrm{o}}(1+x) \prod_{t=1}^{10}\left(1+p_{t}\right)\right]$

As before we first calculate the average present value of this lease when the initial rent is set equal to the rent ( $x$ is zero) on the no-option lease and then compute the premium/discount on the first (and second) 10-year rent that will equate the average of the present values of this lease to that of the first lease. We demonstrate that the premium can be made quite small with the appropriate selection of the ratio of the sales breakpoint to initial expected sales. 


\section{Basic Results}

Table 2 contains our primary results. The first case is based upon two percent expected inflation and a sales threshold equal to 1.27 times initial expected sales. The first row presents the average present values of our four leases, assuming that all begin with a $\$ 10.85$ initial rent (the equilibrium rent on a 10 -year fixed rent lease given that the one-year rent is $\$ 10.00$, obtained by equating equations 2 and 3 and solving), the expected nominal sales drift is the two percent inflation rate, and the discount rate is the four percent real risk-free interest rate plus two percent expected inflation. Zero risk-neutral real sales growth is consistent with different combinations of sales growth and lease risk premium, e.g., two percent real sales growth and a two percent risk premium or zero real sales growth and no risk premium.

The values range from a low of $\$ 121$ for the renewal lease to a high of $\$ 151$ for the overage lease. The former is low because when real sales growth is positive, tenants truncate the eleventh year rent increase to cumulative general inflation since lease origination, but when real sales growth is negative, tenants pay the resultant lower eleventh year real rent. The lease value is highest for the overage contract because when real sales growth is sufficiently positive overages are earned and in no case are negative overages earned. Owing to our judicious setting of the sales threshold, which means that overage rents are not expected $\left(1.02^{\wedge} 10<1.27\right)$, the value of the combined renewal-plus-overage dual-option lease is equal to the value of a 20 -year lease with a single up-ordown adjustment at year eleven, $\$ 134$.

The second row shows the percentage premium and discount, respectively, that must be applied to the $\$ 10.85$ initial rent in order for the renewal and overage leases to be valued at $\$ 134$. The renewal rent premium is a full 17 percent, while the overage rent discount is 11 percent. ${ }^{11}$ Of course, neither a discount nor a premium need be applied to the dual-option lease whose value already equals that of the no-option lease.

\footnotetext{
${ }^{11}$ With a 12 percent discount rate, the base rent for the overage contract is $\$ 9.55$, and with a sales threshold of $\$ 127$ the overage percentage, $\mathrm{f}$, is 0.075 .
} 
The upper part of Figure 1 shows the present-value distributions for the renewal and overage leases based on the two percent inflation assumption. Because the high year eleven rents owing to positive real sales growth are truncated at cumulative general inflation (the tenant exercises the renewal option), there is no positive tail for the renewal lease but rather a heavy loading at the top of the truncated distribution. The overage lease, in contrast, has a long positive tail for the outliers generated by strong sales growth and to offset this tail has a large mass below the mean for the numerous cases of zero overages. The overage lease would "appear" to be significantly riskier than the renewal lease.

The lower part of Figure 1 shows the distributions of the present values for the no-option lease with a single up-or-down adjustment at the end of the tenth year and for our combination dual overage-and-renewal option lease. Not only do the options offset each other so that the values of these two leases are equal, but the tails of the distributions of present values are quite similar. The lower tails are the same because neither option is triggered when sales are low. As for the higher tail on the dual-option lease, when high sales growth provides the tenant with substantial overages during the first decade the renewal option substantially lowers the second decade base rent relative to what it would otherwise be.

Case 2 in Table 2 is based upon an eight percent inflation rate and a correspondingly higher 12 percent nominal discount rate. Again using equations (2) and (3), we obtain a higher $\$ 13.49$ fixed rent for the first ten years. As a result of the higher drift in nominal sales, the overage option is far more valuable - significant overages would be expected by the fourth year $\left(1.08^{\wedge} 3>1.27\right)$. Thus the overage rent discount must be nearly doubled to 22 percent to lower the value of the overage lease to that of the no-option lease. Because the option values no longer offset, a nontrivial 12 percent rent discount is needed to reduce the value of the dual-option lease to that of the nooption lease.

The offset can be reestablished if we limit the impact of the higher sales growth rate on the value of the overage option by raising the sales threshold to 1.72 times expected initial sales. As a 
result overage rents now are not expected until the eighth year $\left(1.08^{\wedge} 7.2=1.72\right)$, and the value of the dual-option lease is again equal to the value of the no-option up-or-down adjustable rent lease. The resulting rent premium/discount, shown as case 3 of Table 2, is similar to that in the two percent inflation case.

Figure 2 shows the distributions of present values for the four leases in the eight percent inflation case. Again, the distributions for the no- and dual-option leases are quite similar, both to each other and to those when inflation was two percent. That is, it is not difficult to put together a combination overage-renewal lease that effectively duplicates the valuation distribution of the 10year-fixed-rent adjustable rent lease. And the distributions for the overage and renewal leases differ enormously.

Further simulations were carried out to see how robust these results were to stochastic interest rates. The Cox, Ingersoll and Ross (1985a) model generates interest rates according to the model,

$$
d r=a(b-r) d t+c \sqrt{ } r d z
$$

where $a, b$ and $c$ are constants. Various values of the constants were tried in the simulations, and equivalent trials to those shown in Table 2 were run. For values of $\mathrm{c}=0.01$ to 0.03 , the results were remarkably similar. At the highest volatilities and with the high inflation (and interest rate) scenario, the value of the no option lease rose very slightly, but this was almost perfectly matched by the accompanying rise in the value of the combined lease. The difference between the no-option and dual-option leases was less than four-hundreds of a percent, and this result held even when the mean-reverting parameter (a) was decreased to emphasize the drifting behavior of interest rates. Because of this insensitivity, the later simulations were run with constant interest rates.

Of course, there is uncertainty regarding the various input parameters, especially the riskneutral growth rate and variance of real tenant sales. The optionality-offsetting ratio of the sales 
threshold to initial expected sales is not very sensitive to the variance of real tenant sales, especially at significant inflation rates. In the two percent inflation world, higher volatility increases the overage option slightly more than the renewal option. Thus the ratios sales threshold to initial sales that eliminate optionality for 10,20 , and 30 percent volatilities are $1.2,1.27$ and 1.33 . In the eight percent inflation world, the ratio is 1.72 for all three volatilities; increasing sales volatility raises the value of the overage and renewal options equally. We now turn to the sensitivity of our results to the risk-neutral real sales growth rate and to the underlying risk premium on real estate. We also report the implied risky discount rates appropriate for valuing the four leases.

\section{Variation in Risk Neutral Growth Rates and Risky Discount Rates}

The valuations performed above were derived in a risk neutral framework. Following Cox, Ingersoll and Ross (1985b) we reduced the expected growth rate of the underlying asset to the riskneutral expected real growth rate in sales, the difference between the expected actual real growth rate and the required risk premium on an investment in an asset whose return has the stochastic properties of retail sales. We employed a zero risk-neutral growth rate, which is consistent with any combination of equal expected real growth rates and risk premia. Here we wish to compute the sensitivity of the required ratio of sales threshold to initial sales to different assumptions regarding the risk neutral growth rate. This requires consideration of the plausible alternative real growth rates and risk premia assumptions.

A plausible range of real growth rates is zero to two percent. The former assumes that real sales growth in the economy is matched by increases in shopping center space, leaving real sales per square foot constant. The latter allows for rising real land prices limiting the increase in space and thus raising sales per square foot. Using the capital asset pricing model, the required risk premium depends on the correlation of the underlying traded asset or portfolio of assets (with the stochastic properties of retail sales) with the market portfolio. If we take retail equity REITs to be the underlying asset, a beta of 0.3 to 0.5 applied to a market risk premium of six to eight percent 
gives a risk premium of two to four percent. On the other hand, if we take the share prices of individual tenants to be the underlying asset, beta would be much lower, giving a risk premium of (say) zero to two percent. Subtracting the zero to four percent plausible risk premium from two and zero percent gives a range of the risk-neutral expected real growth rate from plus two to minus four percent.

Table 3 reports the initial rent on the no-option lease, value, percentage renewal rent premium, percentage overage rent discount and the ratio of initial to threshold sales (that which equates the values of the dual and no option leases) for the alternative assumptions regarding riskneutral real growth rates. We first compute the beginning 10 -year rent consistent with the expected growth rates in one-year rents using equations (2) and (3) and the assumption of a six percent nominal interest rate. We then perform the other calculations. Of course, the higher the riskneutral real growth rate, the greater the value of the lease and the more valuable are the options (the larger are the rent premium and discount). Value is 60 percent higher with the two percent growth rate than with the minus four percent rate and the premium/discount rise by factors of three (overage discount) to five (renewal premium). Because the value of the renewal option rises relative to that of the overage option as the growth rate is increased, the ratio of sales threshold to initial sales must be lowered (the overage option must be moved closer to in the money). For each two-percentage point increase in the growth rate, the ratio falls by 0.04 , i.e., the ratio varies from 1.23 to 1.35 for the six-point variation in the growth rate.

Also of interest is how required risky discount rates (risk free rate plus risk premium) might vary across our different leases. To estimate risky discount rates, we begin with the risk-neutral values and overage lease rent premia and renewal discounts, but use the actual, rather than riskneutral, real growth rates and back out the IRRs (risky discount rates) consistent with these values and assumptions. Table 4 reports these scenarios and the higher initial 10-year rents associated with higher actual, as opposed to risk-neutral, growth rates. These risky discount rates are shown in the last four rows of the table. For the no-option and dual-option leases, the discount rates are 
raised by slightly less (15 basis points) than the two percent increase in the risk premium; the discount rates are raised by 25 to 30 basis points less than the four percent increase in the risk premium.

The discount rates for the overage and renewal option leases are noticeably different. The discount rate for the renewal option lease is 35 to 75 basis points less than that for the no-option and dual-option leases, while the discount rate for the overage option lease is 40 to 90 basis points greater. These differences are larger the greater is the risk premium. They appear to be independent of the inflation rate environment.

The distributions of these IRRs in the simulations mimic those of the present values in Figures 1 and 2: a high discount rate is need to offset the value of a high sales draw and a low discount rate is needed to offset the value of a low sales draw. Figure 3 graphs the cumulative distributions of IRRs for the four leases. Figure 3a contains the near-identical distributions for the no and dual option leases. Figure $3 \mathrm{~b}$ contains the very different distributions for the overage and renewal option leases. It can clearly be seen that the renewal lease stochastically dominates the overage lease in the risk neutral framework. For example, there is virtually no chance of earning a negative real return (two percent nominal) with the renewal lease, but a 25 percent chance with the overage lease. It is because of this dominance that the risky discount rate for the overage lease is 75 to 160 basis points higher than that of the renewal lease.

Failure to use different risky discount rates to value the cash-flow distributions for the different leases will lead to significant valuation errors. The largest error exists in the case of two percent real sales growth and four percent risk premium. The values for the equally-valued (by construction) overage and renewal leases are $\$ 109$ and $\$ 123$, a difference of 12 percent.

\section{Summary and Conclusion}

We began by valuing four different lease contracts that give tenants control over space for twenty years: a no-option single up-or-downward adjusting lease at year eleven, this lease with a 
tenant option to renew at a constant real rent in year eleven, a traditional retail overage rent contract (reset in year eleven), and the latter with a tenant renewal option at year eleven. The calculations are performed under two different inflation assumptions (two and eight percent) for processes generating the price level and real tenant sales. The valuations were initially carried out in a riskneutral environment, i.e., the expected drift in real sales was lowered to zero and a risk-free discount rate was employed (an assumed four percent real rate plus the expected inflation rate).

We next calculated the variation in initial rent levels on the three leases with options that would be required to equate their values to that of the no-option lease, as equilibrium requires. Tenants pay for their renewal option by paying a higher initial rent, roughly a sixth higher in our 20 percent volatility world. Landlords pay for the potential overages by accepting a lower base rent. The percentage reduction in rents depends on where the sales threshold is set relative to initial sales, as well as the expected drift and volatility in sales. When the ratio of the sales threshold to initial sales is set at 1.27 in the low inflation world and 1.72 in the high inflation environment, the base rent is roughly ten percent less than the initial rent on the no-option lease. Moreover, the initial rent on the dual overage-and-renewal option lease equals the initial rent on the no-option lease.

We have also investigated the distributions of potential present values and IRRs for the four lease contracts. The PV and IRR distributions are similar because high sales draws require offsetting high discount rates to maintain value and vice versa. As expected, the distributions for the overage and renewal options differ greatly. The lower base rent on the overage lease shifts the distribution of present values of the cash flows to the left relative to the no-option lease, but the overages arising from high sales push the upper tail of the distribution to the right. In contrast, the higher initial rent on the renewal lease shifts the present-value distribution to the right, but exercise of the renewal option when real rents would otherwise increase sharply truncates the upper tail of the distribution. That is, the distribution of potential present values and IRRs is far wider for the overage lease than the no-option lease and far narrower for the renewal lease. However, both the 
initial rent and the distribution of potential present values and IRRs for the dual overage-andrenewal option lease can be made remarkably similar to those of the no-option lease if the ratio of the sales threshold to initial sales is set appropriately, as we show. And the appropriate ratio is consistent with that observed on U.S. shopping center leases (Eppli et. al., 2000).

Thus if there are good reasons for the tenant and landlord to want one of these options in the lease, e.g., to reduce transaction costs or to induce greater effort by the tenant or the landlord, the other option can be added in such a way that one obtains a distribution of potential 20 -year present values and IRRs that is close to that of the original no-option lease. Further, the process of valuing the dual-option lease does not (need not) differ from that of valuing the no-option lease. One can simply present value two ten-year annuity streams using the appropriate discount rate. That is, "optionality" does not have to be taken into account in the valuation, as long as the setting of the sales threshold relative to the initial expected tenant sales has equated the values of the two options.

We also computed estimates of the risky discount rates for the four leases for two percent and zero expected drifts in real sales and a required risk premium on real estate varying from zero to four percent. To maintain equality between the no-option and dual-option leases in the low inflation case, it was necessary to vary the initial/threshold sales ratio from 1.23 to 1.35 . The discount rates were comparable for the no-option and dual-option leases that had similar distributions of potential present values and IRRs. In contrast, the renewal lease had a half to threequarters percentage point lower risky discount rate, while the overage lease had a half to threequarters percentage point higher discount rate. This is consistent with the intuition that greater dispersions in potential outcomes give rise to higher discount rates. Using the same risky discount rates to value the renewal and overage leases leads to up to a 12 percent difference in valuation of these, by construction, equal-valued assets. This also illustrates the value of risk-adjusted valuation, where only one, rather than three, risk parameters needed to be specified. 


\section{References}

Brueckner, J.J., "Inter-Store Externalities and Space Allocation in Shopping Centers," Journal of Real Estate Finance and Economics, 7, 1993, 5-7.

Colwell, P. and H.J. Munneke, "Percentage Leases and the Advantages of Regional Malls," Journal of Real Estate Research, 15, 1998, 239-252.

Cox, J.C., J.E. Ingersoll and S.A. Ross, "A Theory of the Term Structure of Interest Rates," Econometrica, 53, 1985a, 385-407

Cox, J.C., J.E. Ingersoll and S.A. Ross, “An Intertemporal General Equilibrium of Asset Prices," Econometrica, 53, 1985b, 363-384.

Deng, Y., J.M. Quigley, and R. Van Order, "Mortgage Terminations, Heterogeneity and the Exercise of Mortgage Options," Econometrica, 68, 2000, 275-308.

Eppli, M., P.H. Hendershott, L. Mejia and J. Shilling, "Lease Overage Rent Clauses: Motivation and Use," ARES Conference, April 2000.

Geltner, D. and N. Miller, Commercial Real Estate Analysis and Investments, Prentice Hall, 2001.

Grenadier, S., "Valuing Lease Contracts: A Real Options Approach,” Journal of Financial Economics, 38, 1995, 297-331.

Hughes, W.T. Jr, "Risk Analysis and Asset Valuation: A Monte Carlo Simulation using Stochastic Rents," Journal of Real Estate Finance and Economics, 11, 1995, 177-187.

Hull, J, Options, Futures, and Other Derivatives, Prentice-Hall, $4^{\text {th }}$ ed., 2000.

Hull, J., and A. White, " One Factor Interest Rate Models and the Valuation of Interest Rate Derivative Securities," Journal of Financial and Quantitative Analysis, 28, 1993, 235-254.

McConnell, J. and Schalheim, "Valuation of Asset Leasing Contracts," Journal of Financial Economics, 1983, 237-261.

Miceli, T.J. and C.F. Sirmans, "Contracting with Spatial Externalities and Agency Problems: The Case of Retail Leases," Regional Science and Urban Economics, 25, 1995, 355-372.

Neftci, S.N., An Introduction to Mathematics of Financial Derivatives, Academic Press, 1996.

Pashigan and Gould, "Internalizing Externalities: The Pricing of Space in Shopping Malls," Journal of Law and Economics, 39, 1998a, 115-142.

, "Contracts, Externalities, and Incentives in Shopping Malls: An Empirical Analysis," Stigler Center for the Study of the State and the Economy, working paper no. 143, September 1998b.

Stanton, R. and N. Wallace, "An Empirical Test of a Contingent Claims Lease Valuation Model," presented at the AREUEA Meeting, N.Y., January 2000. 
Vickson, R.G. "Stochastic Dominance for Decreasing Absolute Risk Aversion," Journal of Financial and Quantitative Analysis, X, 1975, 799-811

Ward, C.W.R., "Arbitrage and Investment in Commercial Property," Journal of Business Finance \& Accounting, 9, 1982, 93-108.

Wheaton, W.C., "Percentage Rent in Retail Leasing: The Alignment of Landlord-Tenant Interests," MIT/CRE working paper no. 75, January 1999. 
Table 1: Comparison of rent and sales between store groups and mall types

\begin{tabular}{llllll}
\hline \hline & & $\begin{array}{l}\text { Median } \\
\text { Mull Type and Store Group }\end{array}$ & $\begin{array}{l}\text { Median } \\
\text { of Stores } \\
\text { RentPer } \\
\text { Leaseabl } \\
\text { e Area } \\
\text { Square } \\
\text { Foot }(\$)\end{array}$ & $\begin{array}{l}\text { Median } \\
\text { SalesPer } \\
\text { Square } \\
\text { Foot }(\$) \\
(1)\end{array}$ & $\begin{array}{l}\text { Median } \\
\text { Rent/ } \\
\text { Median } \\
\text { Sales } \\
(5)\end{array}$ \\
& & & & & \\
& & & & & \\
Superregional malls: & & & & & \\
Department stores (owned) & 213 & 135,586 & 1.95 & 131.40 & .015 \\
Department stores (rented) & 147 & 162,790 & 0.87 & 178.34 & .005 \\
Clothing and accessories & 3,098 & 2,828 & 18.58 & 236.56 & .079 \\
Shoes & 1,142 & 1,684 & 22.00 & 258.77 & .085 \\
Food service & 1,230 & 810 & 32.41 & 341.68 & .095 \\
Gift/speciality & 895 & 2,272 & 22.00 & 250.07 & .088 \\
Jewellery & 623 & 1,200 & 42.00 & 555.48 & .076 \\
Regional malls: & & & & & \\
Department stores (owned) & 139 & 80,000 & 3.00 & 126.15 & .024 \\
Department stores (rented) & 85 & 118,000 & 1.70 & 134.19 & .013 \\
Clothing and accessories & 1,566 & 2,853 & 15.42 & 204.67 & .075 \\
Shoes & 594 & 2,123 & 18.00 & 211.51 & .085 \\
Food service & 800 & 899 & 24.18 & 258.25 & .094 \\
Gift/speciality & 477 & 2,574 & 17.00 & 200.00 & .085 \\
Jewellery & 376 & 1,182 & 36.60 & 499.30 & .073 \\
& & & & & \\
\hline \hline
\end{tabular}

Source: Urban Land Institute, Dollars and Cents of Shopping Centres (1993). Reproduced from Pashigian and Gould (1998a). 
Table 2: Values and the Rent Premium/Discount for Leases with Different Contract Terms

\begin{tabular}{|c|c|c|c|c|c|}
\hline \multirow{3}{*}{$\begin{array}{r}\text { Case } 1 \\
\text { Inflation }=2 \% \\
\text { ST/So }=\mathbf{1 . 2 7} \\
\text { Initial Rent } \\
=\$ 10.85\end{array}$} & & $\begin{array}{l}\text { No-option } \\
\text { Lease }\end{array}$ & $\begin{array}{l}\text { Renewal } \\
\text { Option } \\
\text { Lease }\end{array}$ & $\begin{array}{l}\text { Overage } \\
\text { Option } \\
\text { Lease }\end{array}$ & $\begin{array}{l}\text { Dual } \\
\text { Option } \\
\text { Lease }\end{array}$ \\
\hline & Value (no premium) & $\$ 134$ & $\$ 121$ & $\$ 152$ & $\$ 134$ \\
\hline & Premium/Discount & 0 & $17 \%$ & $-12 \%$ & 0 \\
\hline \multirow{2}{*}{$\begin{array}{r}\text { Case 2 } \\
\text { Inflation }=8 \% \\
\text { ST/So }=\mathbf{1 . 2 7} \\
\text { Initial Rent } \\
=\$ 13.49\end{array}$} & Value (no premium) & $\$ 129$ & $\$ 117$ & $\$ 165$ & $\$ 146$ \\
\hline & Premium/Discount & 0 & $16 \%$ & $-22 \%$ & $-12 \%$ \\
\hline \multirow[t]{2}{*}{$\begin{array}{r}\text { Case 3 } \\
\text { Inflation }=8 \% \\
\text { ST/So }=\mathbf{1 . 7 2} \\
\text { Initial Rent } \\
=\$ 13.49\end{array}$} & Value (no premium) & $\$ 129$ & $\$ 117$ & $\$ 144$ & $\$ 129$ \\
\hline & Premium/Discount & 0 & $16.5 \%$ & $-10.5 \%$ & 0 \\
\hline
\end{tabular}

Table 3: Values and Premia/Discounts Associated with Risk Neutral Growth Rates

\begin{tabular}{|c|c|c|c|c|}
\hline $\begin{array}{r}\text { Risk Neutral } \\
\text { Real Sales } \\
\text { Growth }\end{array}$ & $-4 \%$ & $-2 \%$ & $0 \%$ & $2 \%$ \\
\hline Initial Rent & 9.23 & 10.00 & 10.85 & 11.66 \\
\hline $\begin{array}{r}\text { Risk Neutral } \\
\text { Value }\end{array}$ & $\$ 99$ & $\$ 115$ & $\$ 134$ & $\$ 158$ \\
\hline $\begin{array}{c}\text { Renewal } \\
\text { Premium }\end{array}$ & $5 \%$ & $10 \%$ & $17 \%$ & $27 \%$ \\
\hline $\begin{array}{l}\text { Overage } \\
\text { Discount }\end{array}$ & $5 \%$ & $8 \%$ & $11 \%$ & $15 \%$ \\
\hline $\mathrm{S}_{\mathrm{T}} / \mathrm{S}_{0}$ & 1.35 & 1.31 & 1.27 & 1.23 \\
\hline
\end{tabular}

Table 4: Internal Rates of Return (IRRs) Consistent with Risk Neutral Values

\begin{tabular}{|r|l|l|l|l|}
\hline $\begin{array}{r}\text { Actual Real } \\
\text { Growth }\end{array}$ & 0 & 0 & $2 \%$ & $2 \%$ \\
\hline Risk Premium & $4 \%$ & $2 \%$ & $4 \%$ & $2 \%$ \\
\hline Risk Neutral Value & $\$ 99$ & $\$ 115$ & $\$ 115$ & $\$ 134$ \\
\hline Initial Rent & $\$ 10.78$ & $\$ 10.84$ & $\$ 11.65$ & $\$ 11.72$ \\
\hline No Option & $9.75 \%$ & $7.85 \%$ & $9.70 \%$ & $7.85 \%$ \\
\hline Renewal Option & $9.10 \%$ & $7.50 \%$ & $8.95 \%$ & $7.35 \%$ \\
\hline Overage Option & $10.50 \%$ & $8.25 \%$ & $10.60 \%$ & $8.35 \%$ \\
\hline Dual Option & $9.75 \%$ & $7.85 \%$ & $9.70 \%$ & $7.85 \%$ \\
\hline
\end{tabular}


Figure 1 a): Distributions of Renewal and Overage Lease Values (Low Inflation)

e

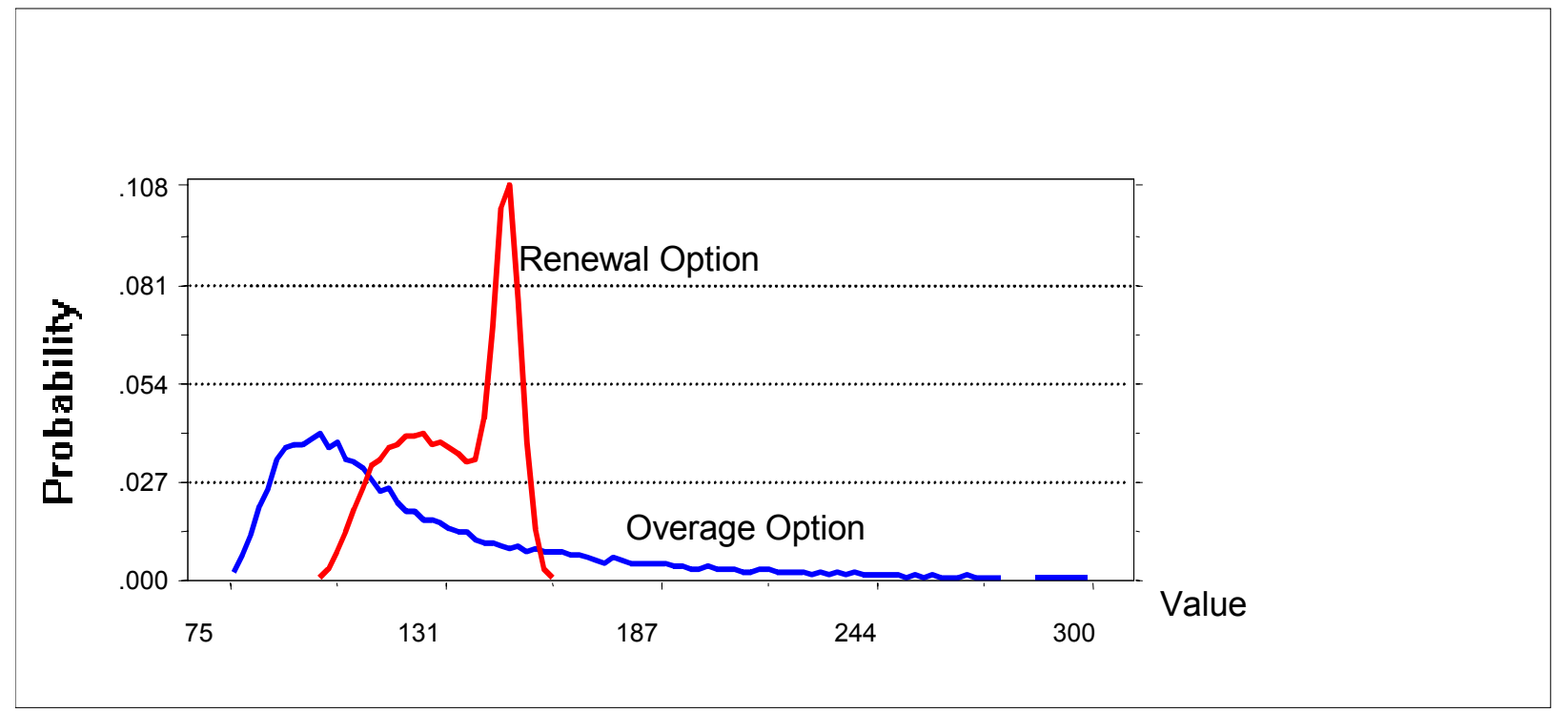

Figure 1 (b): Distributions of No-Option and Dual Option Lease Values (Low Inflation)

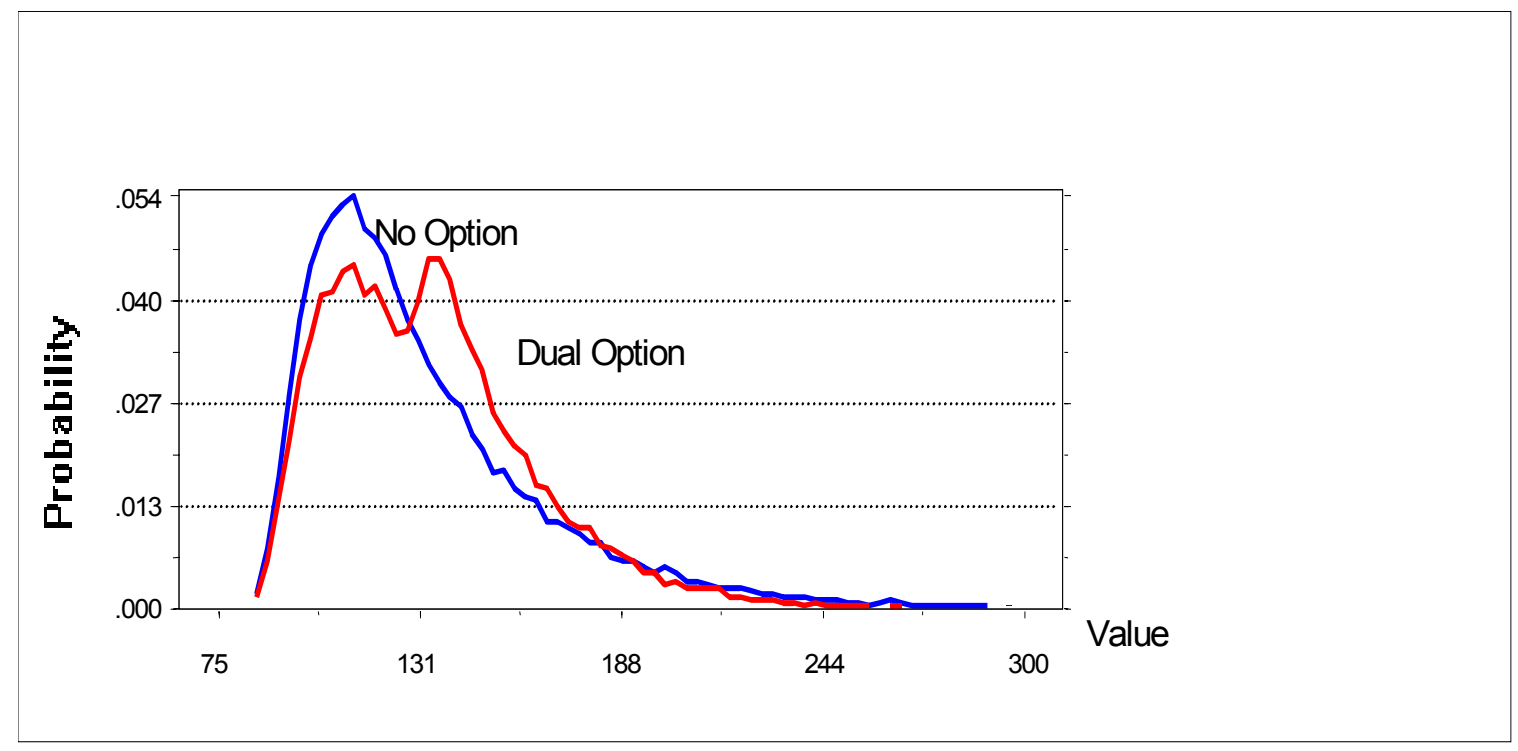


Figure 2 (a): Distributions of Renewal and Overage Lease Values (High Inflation)

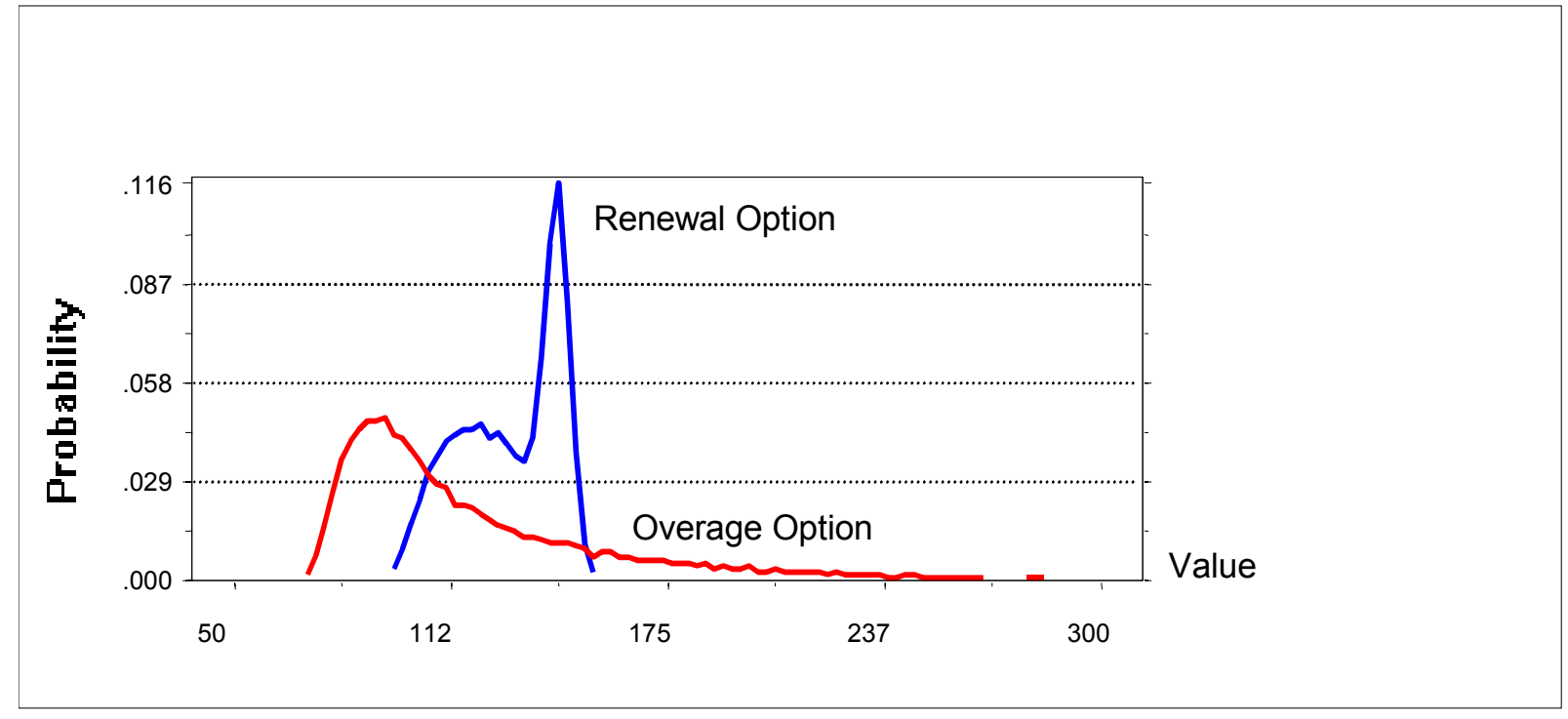

Figure 2 (b): Distributions of No-Option and Dual Option Lease Values (High Inflation)

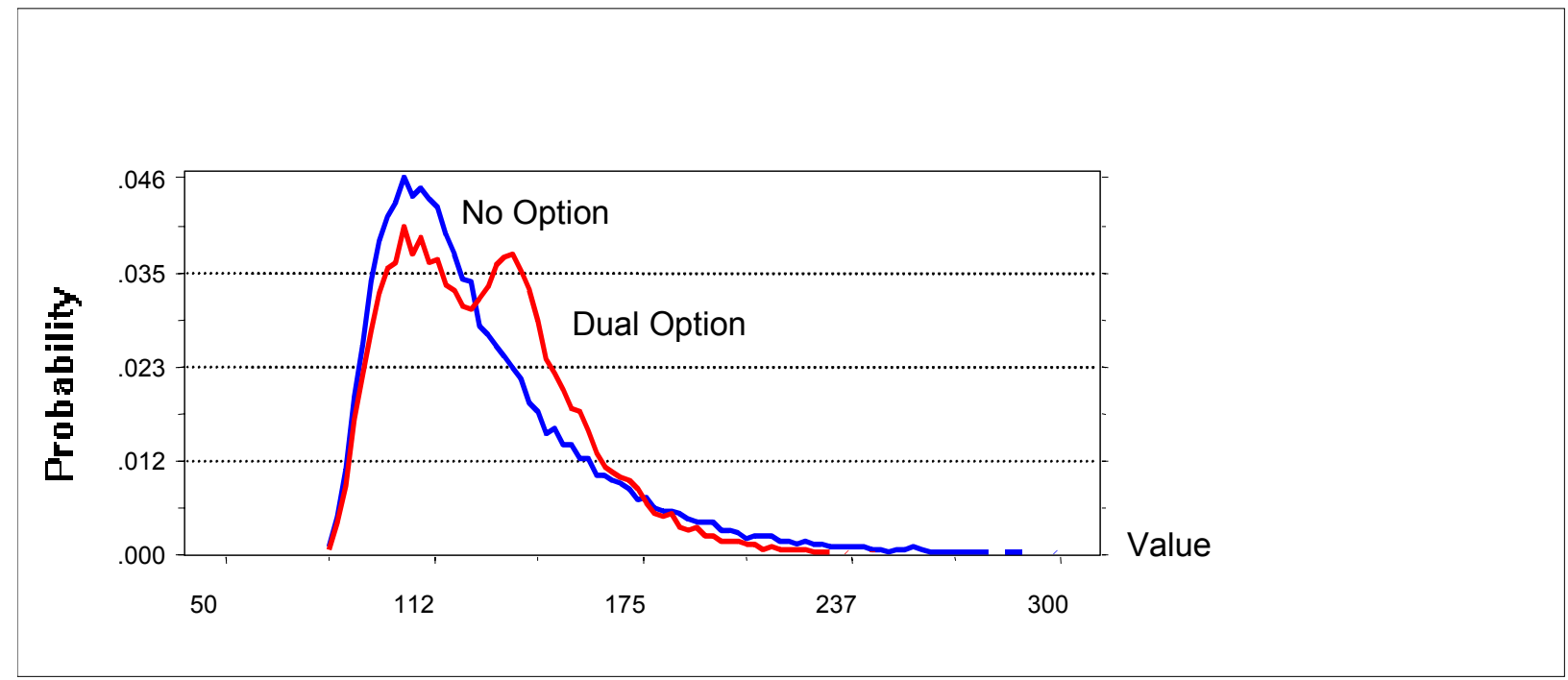


Figure 3 (a): Cumulative IRR Distributions for No- and Dual-Option Leases

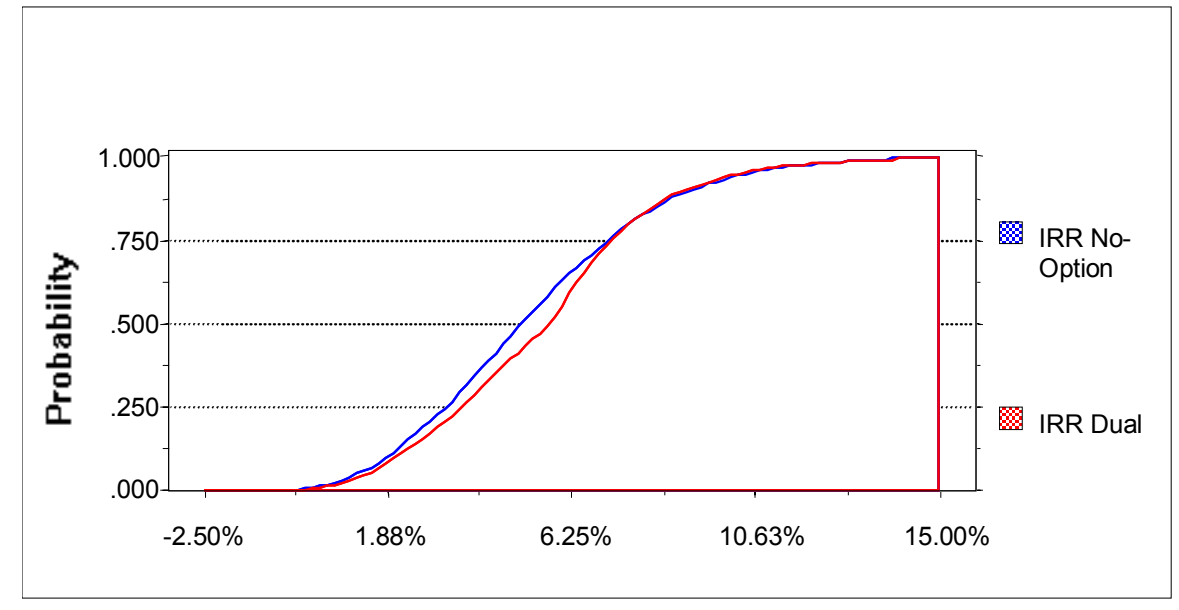

Figure 3 (b): Cumulative IRR Distributions for Renewal and Overage Leases

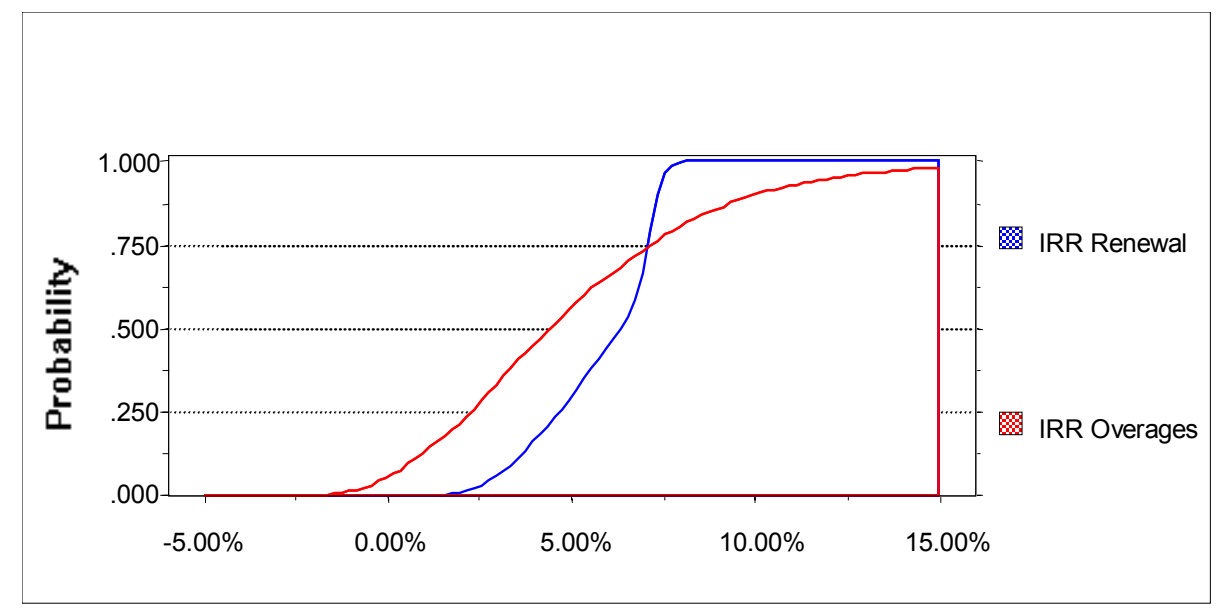




\section{Appendix: Market Rent Based on Ten-Year Rental Growth}

As discussed in the text, it could be more reasonable to assume that some tenants who do not have or do not exercise a renewal option will pay rents in the eleventh year based on area market rents, rather than on specific tenant sales. In this appendix we show how respecifying the eleventh year rent in the absence of exercise of a renewal option alters our simulated lease and option values and terms. The key is how the expected drift and volatility in market rents differs from that of individual tenant sales. There is no reason to think that the expected drifts will in general be different, but the volatility of area market rents is certainly far less than that of individual tenant sales. We assume the same real drift of two percent, but a volatility of only five percent, rather than 20 percent.

Case 1 of Table A illustrates the importance of the lower volatility. Here, all the other assumptions are those of Case 1 of Table 2 in the text. The value of the overage lease is unchanged. While the distribution of possible rents tenants will pay in year eleven has been sharply narrowed because it depends on the five percent volatility of real rents rather than the 20 percent volatility of real sales, the mean rent paid is unchanged and that is all that matters in the average valuation. The value of the renewal option (the difference between the values of the no-option and renewal option leases), on the other hand, falls by over 75 percent; the value of being able to truncate real rent growth by renewing based on cumulative general inflation is not nearly as valuable because the distribution of real rental growth is much tighter than that of real sales growth.

Given that the overage option is still worth a lot to the landlord, but the renewal option is no longer worth much to the tenant, the combined option now has substantial value. Computing value by present valuing first the initial rent and then that rent inflated for ten years would substantially understate the value of the dual-option lease. This understatement can be eliminated by lowering the value of the overage lease via an increase of the sales breakpoint to 2.0 times initial expected sales, i.e., by lowering the value of the overage option. This result is shown as Case 2 in Table A.

Table A: Values and Rent Premia for Leases with Different Contract Terms when the Tenth Year Rent Adjusts to the Growth in Market Rent, not Individual Tenant Sales

\begin{tabular}{|l|l|l|l|l|l|}
\hline $\begin{array}{l}\text { Case } 1 \\
\text { Inflation }=2 \% \\
\text { ST/So }=\mathbf{1 . 2 7} \\
\text { Initial Rent }=\$ 10.85\end{array}$ & $\begin{array}{l}\text { No- } \\
\text { option } \\
\text { Lease }\end{array}$ & $\begin{array}{l}\text { Renewal } \\
\text { Option } \\
\text { Lease }\end{array}$ & $\begin{array}{l}\text { Overage } \\
\text { Option } \\
\text { Lease }\end{array}$ & $\begin{array}{l}\text { Dual } \\
\text { Option } \\
\text { Lease }\end{array}$ \\
\cline { 2 - 6 } & Value (no premium) & $\$ 134$ & $\$ 131$ & $\$ 152$ & $\$ 146$ \\
\cline { 2 - 6 } & Premium/Discount & 0 & $4 \%$ & $-10 \%$ & $-7.5 \%$ \\
\hline $\begin{array}{l}\text { Case } 2 \\
\text { Inflation }=2 \% \\
\text { ST/So }=\mathbf{2 . 0} \\
\text { Initial Rent }=\$ 10.85\end{array}$ & Value (no premium) & $\$ 134$ & $\$ 131$ & $\$ 137$ & \\
\cline { 2 - 6 } & Premium/Discount & $0 \%$ & $4 \%$ & $-2 \%$ & $0 \%$ \\
\hline
\end{tabular}

